\title{
Correction to: Tralokinumab: First Approval
}

\section{Sean Duggan ${ }^{1}$}

Published online: 17 September 2021

(c) Springer Nature 2021

\section{Correction to: Drugs (2021)}

https://doi.org/10.1007/s40265-021-01583-1

Section 2.3.1, right hand column, second paragraph, second sentence, which currently reads:

“... for tralokinumab $300 \mathrm{mg}$ every 2 weeks and tralokinumab 300 mg every 2 weeks, respectively."

Should read:

“... for tralokinumab $300 \mathrm{mg}$ every 2 weeks and tralokinumab $300 \mathrm{mg}$ every 4 weeks, respectively."

Section 2.3.2.1, second paragraph, third sentence, which currently reads:

"Over the 16 week treatment period, patients receiving tralokinumab $300 \mathrm{mg}$ every 2 weeks used 50\% less of the supplied TCS compared with patients receiving placebo"
Should read:

"At weeks 15-16, patients receiving tralokinumab $300 \mathrm{mg}$ every 2 weeks used $50 \%$ less of the supplied TCS compared with patients receiving placebo"

The original article has been corrected.

Open Access This article is licensed under a Creative Commons Attribution-NonCommercial 4.0 International License, which permits any non-commercial use, sharing, adaptation, distribution and reproduction in any medium or format, as long as you give appropriate credit to the original author(s) and the source, provide a link to the Creative Commons licence, and indicate if changes were made. The images or other third party material in this article are included in the article's Creative Commons licence, unless indicated otherwise in a credit line to the material. If material is not included in the article's Creative Commons licence and your intended use is not permitted by statutory regulation or exceeds the permitted use, you will need to obtain permission directly from the copyright holder. To view a copy of this licence, visit http://creativecommons.org/licenses/by-nc/4.0/.

The original article can be found online at https://doi.org/10.1007/ s40265-021-01583-1.

Sean Duggan

dru@adis.com

1 Springer Nature, Mairangi Bay, Private Bag 65901, Auckland 0754, New Zealand 